\title{
Students' perception towards Malay folklore songs
}

\begin{abstract}
This study focuses on studentsôperception towards Malay folklore songs. The objectives of the study were to identify and discuss studentsôperception towards the Malay folklore songs. The samples of the study were 200 subjects from Universiti Putra Malaysia. A set of questionnaires were distributed to the students. The questionnaire consists of studentsô perception towards the Malay folklore song. The songs were music arranged by using the modern pop genre and the lyrics were written to ensure the originality of the stories. Five Malay folklore songs were heard in the classroom. The songs entitled, óBird of Paradiseô óWhy do Crows have Black Feathers?Q̂ óBirdsô Leaderô óThe Mermaid Riverô and óThe Flamingo and the Deerô The data from the questionnaires were analysed by using the percentage. The results of the study revealed that majority of the subjects strongly agreed and agreed that the lyrics of the songs were simple and well understood, the storylines were interesting and intelligible and also, the music for the songs were suitable and interesting. It is hoped that further study will focus on other Malay folklore songs for students at schools.
\end{abstract}

Keyword: Malay folklore song; Intelligible; Interesting; Perception 